\title{
Relaxation Motions Induced in Bacillus subtilis Macrofibres by Cleavage of Peptidoglycan
}

\author{
By DIDIER FAVRE, ${ }^{2} \dagger$ NEIL H. MENDELSON ${ }^{1 *}$ AND J. J. THWAITES 3 \\ ${ }^{1}$ Department of Molecular and Cellular Biology, University of Arizona, Tucson, AZ 85721, USA \\ ${ }^{2}$ Institut de Génétique et de Biologie Microbiennes, Université de Lausanne, 1005 Lausanne, \\ Switzerland ${ }^{3}$ Department of Engineering, Cambridge University, Cambridge CB2 IPZ, UK
}

(Received 21 October 1985; revised 24 March 1986)

\begin{abstract}
Bacillus subtilis macrofibres exposed to lysozyme underwent characteristic rotations, termed relaxation motions, in which their twist changed. Intact macrofibres and macrofibre fragments devoid of loop ends responded in the same way. Macrofibre strains for which the helix hand is temperature-dependent and also those of fixed-hand (both left and right) underwent initial relaxation motions towards the right-hand end of the twist spectrum, the only exception being those in which the initial twist state was at or near the right-hand maximum. Often when the initial relaxation motions were completed immediately before structure breakdown the macrofibres underwent one or a few rotations in the opposite direction (towards the left-hand end of the twist spectrum). Crude autolysin extract obtained from wild-type $B$. subtilis also caused macrofibre relaxation motions at $\mathrm{pH} 5.6$ but at $\mathrm{pH} 8.0$ macrofibre breakdown occurred as a result of septal cleavage. This resulted in the release of helically shaped individual cellular filaments. These findings suggest that strain in the cell wall associated with helical shape was dependent on the integrity of the glycan backbone rather than peptide cross-bridges. In contrast, cleavage of peptide cross-bridges apparently was instrumental in the cell separation process. Left- and right-hand macrofibres, when exposed to lysozyme, exhibited different rates of relaxation, breakdown of fibre structure and protoplast formation. Similarly, the rate of macrofibre breakdown during the lag between temperature shift and inversion reflected the replacement of septal wall material by that of a new conformation corresponding to the new helix hand. The difference in the rates of protoplast formation indicates asymmetry in the overall rate of cleavage by lysozyme which may reflect the activity of left-twist protein(s).
\end{abstract}

\section{INTRODUCTION}

The spectrum of possible twists in macrofibres of Bacillus subtilis strain $\mathrm{FJ} 7$, from tight righthanded through neutral to tight left-handed, indicates a range of states of differentiation, all of which can be achieved by the same starting cell. We have begun to explore the major factors responsible for the determination and maintenance of the macrofibre twist state and have identified five: (i) a biomechanical factor, (ii) the peptidoglycan state, (iii) left-twist protein(s), (iv) electrostatic interactions in the cell wall and (v) water effects in terms of hydrophobic/hydrophilic interactions of cell wall polymers (Mendelson et al., 1985). We believe that understanding the factors that govern helical growth in the macrofibre system will also provide insight into those governing normal cell growth, shape determination and maintenance.

In previous work (Mendelson et al., 1984) we presented evidence that macrofibre geometry reflects individual cell wall organization in an amplified form, and we have argued that because of this relationship it is possible to use the macrofibre system to explore properties of the cell wall. We have suggested that the cell wall conformation can vary over a spectrum that

† Present address: Départment Biochimie Médicale, Université de Genève, 1211 Genève 4, Switzerland. 
corresponds to the macrofibre twist spectrum (Mendelson et al., 1984). Moreover, macrofibres appear to be strained structures, and we have found evidence indicating that the outer portion of the cell wall plays an important role in the maintenance of the helical shape deformation (Favre et al., 1985a, b).

The use of macrofibres to probe cellular organization and even molecular properties of the cell wall involves operationally the study of macrofibre behaviour resulting from the activities of the individual cells that comprise the multicellular structures. Four levels of organization must therefore be kept in mind: (i) the properties of the cell wall, (ii) the properties of the separationsuppressed cellular filaments, (iii) the properties of the helical bundles that form the core of macrofibres and (iv) the superstructure organization of the core bundles. Previous work has dealt with the relationship between $(a)$ helical growth (level ii) and cell wall organization (level i) (Mendelson, 1976); (b) the growth of individual filaments (level ii) and production of macrofibres (levels iii and iv) (Mendelson, 1982); (c) macrofibre twist (levels iii and iv) and helical growth of individual filaments (levels i and ii) (Mendelson, et al., 1985); and (d) cell wall macromolecules (level i) and helical twist (levels ii and iii) (Favre et al., 1985a).

This paper is concerned with the role of peptidoglycan in macrofibre twist maintenance, and in helical shape determination.

\section{METHODS}

Bacterial strains. The mutants of Bacillus subtilis strain 168 used in this study are listed in Table 1.

Media. For cultivation of macrofibres by standard techniques the complex medium TB was used (Mendelson, $1976,1978)$. For production of protoplasts the medium used contained one volume of twice-concentrated SMM (1 M-sucrose, $0.03 \mathrm{M}$-maleic acid, $0.04 \mathrm{M}-\mathrm{MgCl}_{2} .6 \mathrm{H}_{2} \mathrm{O}$, pH 6.5) mixed with one volume of four-times concentrated PAB (Difco antibiotic medium \#3, 7\%,v/v) and supplemented with $2 \%(\mathrm{w} / \mathrm{v}) \mathrm{BSA}$. Macrofibres suspended in this mixture were converted to protoplasts by addition of fresh lysozyme $\left(5 \mathrm{mg} \mathrm{ml}^{-1}\right)$. For production of autolysins

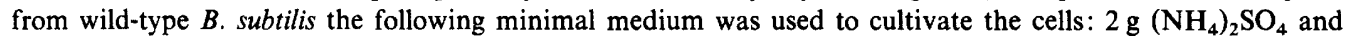
$0.2 \mathrm{~g} \mathrm{~K}_{2} \mathrm{HPO}_{4} \cdot 3 \mathrm{H}_{2} \mathrm{O}$, per litre of $\mathrm{H}_{2} \mathrm{O}$ containing $0.05 \%(\mathrm{w} / \mathrm{v})$ Casamino acids, $0.5 \%(\mathrm{w} / \mathrm{v})$ sodium lactate and $20 \mu \mathrm{g} \mathrm{ml}^{-1}$ of the required bases and amino acids. Lysozyme (chicken egg white, crystallized three times) was obtained from Sigma.

Microcinematography. The methods used for film production and analysis were previously described (Mendelson, 1982). Lysozyme-induced motions were filmed at the highest possible rate of 0.5 frames $\mathrm{s}^{-1}$.

Preparation of crude extract containing autolysins. Minimal medium ( 1 to 1.51 ) containing sodium lactate was seeded with two to three fresh colonies of $B$. subtilis 168 . The cultures were incubated for $18 \mathrm{~h}$ at $37^{\circ} \mathrm{C}$ to stationary phase $\left(\mathrm{OD}_{660} 0.75\right.$ to 1.0$)$. The cells were collected by centrifugation for $15 \mathrm{~min}$ at 5000 r.p.m., washed by resuspension in $30 \mathrm{ml}$ double-distilled water at $4{ }^{\circ} \mathrm{C}$, collected by centrifugation as above and the wet weight recorded. The autolytic enzymes were extracted by resuspending the cells in $5 \mathrm{M}-\mathrm{LiCl}(5 \%$, w/v, wet weight cells) and incubating the mixture at $4{ }^{\circ} \mathrm{C}$ for 1 to $2 \mathrm{~h}$. The cells were pelleted by centrifugation $(10 \mathrm{~min}, 5000 \mathrm{r} . \mathrm{p} . \mathrm{m}$.) and

\section{Table 1. B. subtilis 168 strains used in this study}

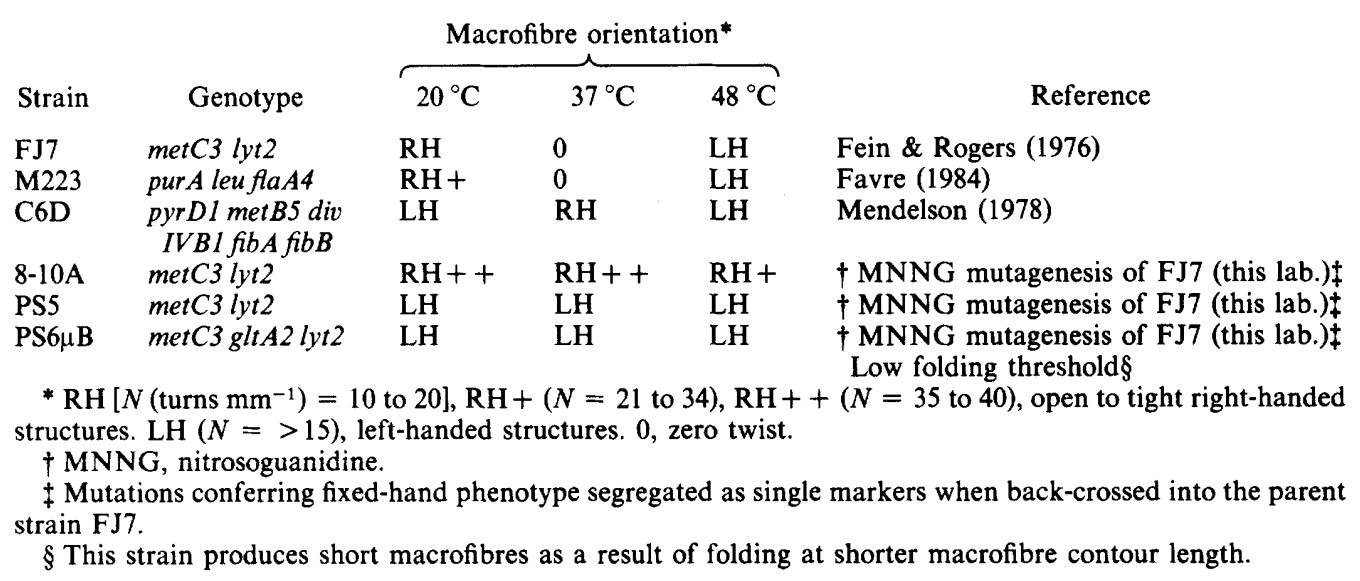


the supernatant was sterilized by filtration through a Gelman membrane $(0.45 \mu \mathrm{m}$ pore size $)$. The extract was then dialysed against three changes of $410.01 \mathrm{M}$-Tris/ $\mathrm{HCl}$ buffer, $\mathrm{pH} 7 \cdot 0$, and lyophilized. The lyophilized material was rehydrated in one-ffth the original volume of double-distilled, sterile water.

Measurement of maximum relaxation rate induced by lysozyme. Samples containing five to ten macrofibres were quickly cooled to $4^{\circ} \mathrm{C}$. One macrofibre contained in a $10 \mu \mathrm{l}$ drop of cold medium was transferred into 5 to $10 \mathrm{ml}$ TB medium (at about $24^{\circ} \mathrm{C}$ ) containing 0.1 to $1 \mathrm{mg}$ lysozyme $\mathrm{ml}^{-1}$. Relaxation motions were observed microscopically. The time to start rotation and the time taken for each subsequent half-revolution were recorded. We observed only lateral extensions protruding from large macrofibres in which the proximal end was fixed by virtue of being embedded into the shaft of the macrofibre, being therefore unable to rotate. In order to minimize lysozyme gradient effects between the outside and inside of the macrofibres only those consisting of two to eight cellular filaments and approximately $30 \mu \mathrm{m}$ in length were measured.

Determination of the rate of attack by lysozyme. The rates of lysozyme-induced cell macrofibre breakdown were determined using methods described by Mendelson et al. (1984). The breakdown time was that taken for the entire structure to disappear when viewed stereoscopically at low magnification.

\section{RESULTS}

\section{Effect of lysozyme digestion on right-and left-handed macrofibres}

Intact macrofibres or macrofibre fragments consisting of a short length cut or sheared from an intact structure derived from strains FJ7 and M223 (the helix hand of which depends on temperature), left-handed strains C6D and PS-5, and the fixed-right-handed strain 8-10A were produced at the temperatures indicated in Table 2 and either $20 \mathrm{~mm}-\mathrm{NaN}_{3}$ or $1 \%(\mathrm{w} / \mathrm{v})$ formaldehyde was added to inhibit growth and metabolism. The structures were then treated with lysozyme as described and their relaxation motions and time to breakdown were observed.

In nearly all cases, the initial rotation was in the right-handed direction, that is in the direction characteristic of steady state growth of right-handed macrofibres. This involved the opening of left-handed structures in contrast to the tightening of right-handed ones. If the starting material was a short left-handed fragment the final structure was often right-handed. In whole macrofibres, such extreme conformational change was often masked either by folding into a right-handed superstructure in which individual filaments retained left-hand twist (Fig. 1), or by breakdown of the macrofibre due to septal cleavage. Left-handed macrofibres began turning about $5 \mathrm{~s}$ after transfer into lysozyme whereas right-handed ones began after about 10 to $15 \mathrm{~s}$. Left-hand macrofibres completed $80 \%$ of their relaxation motions after 20 to $40 \mathrm{~s}$. For righthanded macrofibres the duration of turning ranged from a few seconds to several minutes and

Table 2. Lysozyme-induced relaxation and macrofibre breakdown*

\begin{tabular}{|c|c|c|c|c|c|}
\hline \multirow[b]{2}{*}{ Strain } & \multirow{2}{*}{$\begin{array}{c}\text { Growth } \\
\text { temperature } \\
\left({ }^{\circ} \mathrm{C}\right)\end{array}$} & \multirow{2}{*}{$\begin{array}{l}\text { Start of } \\
\text { relaxation } \\
\text { (s) } \dagger\end{array}$} & Twist $\ddagger$ & \multirow{2}{*}{$\begin{array}{l}\text { Time to } \\
\text { breakdown } \\
\text { (min) }\end{array}$} & \multirow[b]{2}{*}{ Folding $\|$} \\
\hline & & & After lysozyme & & \\
\hline FJ7 & 20 & $10-15$ & RH-slow $\$$ RH $+\rightarrow$ RH & $98 \pm 5$ & - \\
\hline $\mathrm{FJ} 7$ & 48 & $5-10$ & $\begin{array}{l}\text { LH }+ \text {-fast } \rightarrow \text { RH } \rightarrow \text { Sep } \\
0-\text { fast } \rightarrow \text { RH }++\rightarrow \text { RH } \rightarrow \text { Sep }\end{array}$ & $11 \pm 1$ & + \\
\hline C6D & 20 or 48 & $5-7$ & $\begin{array}{l}\mathrm{LH}++- \text { fast } \rightarrow \mathrm{LH} \rightarrow \mathrm{Sep} \\
0-\text { fast } \rightarrow \mathrm{RH}++\rightarrow \operatorname{Sep}\end{array}$ & $8 \pm 1$ & $\overline{+}$ \\
\hline C6D & 37 & $10-15$ & $\mathrm{RH}-$ slow $\rightarrow \mathrm{RH}+\rightarrow$ Sep & $70 \pm 5$ & - \\
\hline $8-10 \mathrm{~A}$ & 20 or 48 & $15-20$ & $\mathrm{RH}++-$ slow $\rightarrow \mathrm{RH}+++\rightarrow \mathrm{RH}$ & $120 \pm 8$ & - \\
\hline $\begin{array}{l}\text { PS5 or } \\
\text { PS6 } \mu \mathrm{B}\end{array}$ & 20 or 48 & $5-7$ & $\begin{array}{l}\mathrm{LH}++- \text { fast } \rightarrow \mathrm{RH} \rightarrow \mathrm{Sep} \\
0-\text { fast } \rightarrow \mathrm{RH}++\rightarrow \text { Sep }\end{array}$ & $7 \pm 1$ & $\overline{+}$ \\
\hline
\end{tabular}

* After the addition of 0.1 to $1 \mathrm{mg}$ lysozyme $\mathrm{ml}^{-1}$.

$\uparrow$ Time between lysozyme addition and the start of relaxation.

$\ddagger$ RH to $\mathrm{RH}++$, open to tight right-handed structures; $\mathrm{LH}$ to $\mathrm{LH}++$, open to tight left-handed structures; 0 , zero twist; Sep, cell separation and the breakdown of macrofibre structure.

$\S$ Rate of turning from direct observations.

$\|-$, no fold; + , folding during relaxation. Usually only intact left-handed macrofibres produce a fold. 


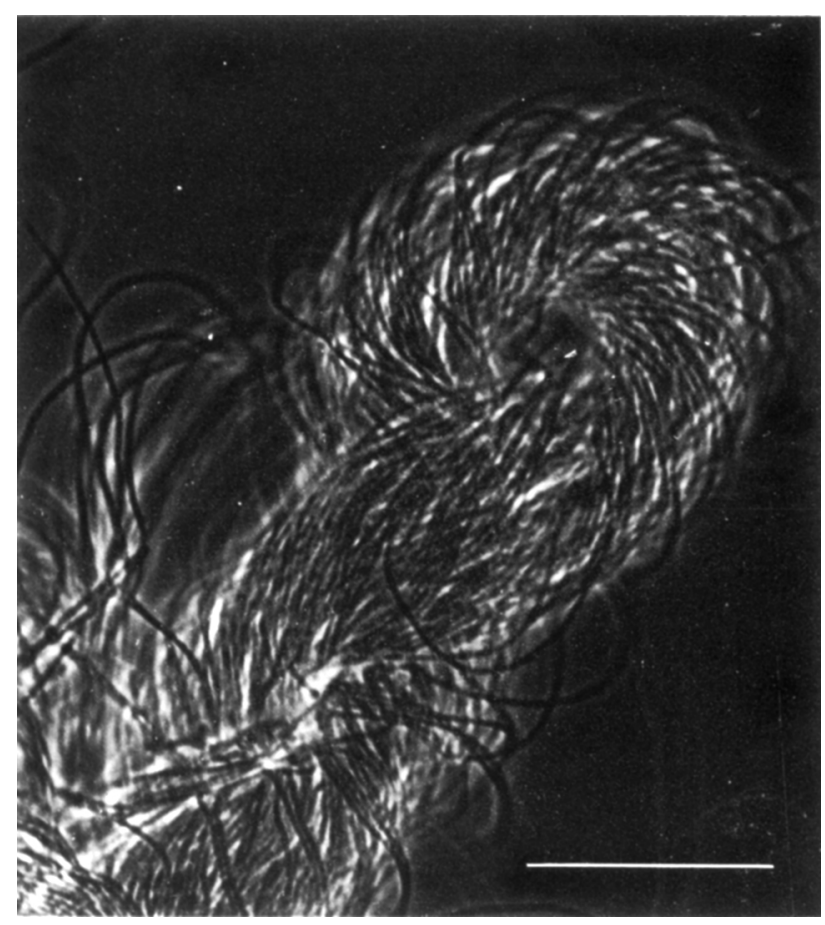

Fig. 1. Phase contrast micrograph of a left-handed macrofibre that has folded to produce right-handed superstructure. Macrofibres of strain PS5 produced at $20^{\circ} \mathrm{C}$ in TB medium (left-handed) were transferred into TB medium containing $0.1 \mathrm{mg}$ lysozyme $\mathrm{ml}^{-1}$. Relaxation motions produced a righthanded fold and plying resulting in a right-handed superstructure whereas the substructure remained left-handed. Bar $=30 \mu \mathrm{m}$.

the tightening was sometimes followed by opening due to left-hand turning, the extent of which depended on the initial twist. In strain FJ7, for example, the initial right-hand twist was low. When exposed to lysozyme the macrofibres tightened considerably, then one or two left-handed rotations caused them to open just before their breakdown. Strain 8-10A, a fixed-hand mutant that grows with high right-hand twist, responded to lysozyme by little if any tightening, quickly followed by left-hand turning that continued until the structures had nearly zero twist (Table 2). In general however, the initial and predominant response of macrofibres to lysozyme digestion was right-hand turning regardless of the initial twist of the structures. We interpret these findings to indicate that the cell wall in macrofibres is under torsional stress. In this system the peptidoglycan appears to be a strained structure that relaxes when the glycan backbone is cut.

The difference in response to lysozyme attack between macrofibres whose twists are at the extremes of the twist spectrum (right and left) is shown in Table 2. The rates of both relaxation and fibre breakdown were greater in left- than in right-handed structures. The rate of relaxation motions as well as their nature appeared not to be influenced by the medium in which the reactions occurred. Relaxation motions occurred whenever macrofibres were exposed to $0.05 \mathrm{mg}$ or more of lysozyme $\mathrm{ml}^{-1}$, but if macrofibres were exposed to either chemically inactivated lysozyme (incubated in $10 \mathrm{M}$-urea, $0.05 \mathrm{M}$-dithiothreitol for $12 \mathrm{~h}$ at room temperature as described by Imoto et al., 1972), or to polylysine in the same $M_{\mathrm{r}}$ range as lysozyme, no relaxation or other motions were observed. We believe therefore that the response to lysozyme described above and by Mendelson et al. (1984) resulted from enzymic cleavage of the peptidoglycan. 
Table 3. Relaxation induced by a crude extract of autolytic enzymes*

\begin{tabular}{|c|c|c|c|c|c|c|c|}
\hline Strain & $\begin{array}{c}\text { Temperature } \\
\left({ }^{\circ} \mathrm{C}\right)\end{array}$ & $\begin{array}{l}\text { Macrofibre } \\
\text { orientation }\end{array}$ & $\mathrm{pH} \dagger$ & Relaxation $\ddagger$ & $\begin{array}{l}\text { Start of } \\
\text { relaxation } \\
(\min )\end{array}$ & $\begin{array}{c}\text { Macrofibre } \\
\text { breakdown§ }\end{array}$ & $\begin{array}{l}\text { Time to } \\
\text { breakdown } \\
\text { (min) }\end{array}$ \\
\hline FJ7 & 20 & RH & $5 \cdot 6$ & Tightening & 2 & - & \\
\hline FJ7 & 20 & $\mathrm{RH}$ & $8 \cdot 0$ & None & & + & 15 \\
\hline FJ7 & 48 & $\mathrm{LH}$ & $5 \cdot 6$ & Opening & 1 & - & \\
\hline FJ7 & 48 & LH & $8 \cdot 0$ & None & & + & 15 \\
\hline C6D & 20 & LH & $5 \cdot 6$ & Opening & 1 & - & \\
\hline C6D & 20 & LH & 8.0 & None & & + & 15 \\
\hline
\end{tabular}

* Crude extract consisted of a $5 \mathrm{M}-\mathrm{LiCl}$ extract from whole cells of strain 168.

+ pH 5.6 favours glucosaminidase activity, $\mathrm{pH} 8.0$ favours amidase activity.

$\ddagger$ Qualitative evaluations from observations on live or fixed ( $1 \%$ formaldehyde) macrofibres. The same results were obtained in both cases.

$\S-$, No effect; + , breakdown into single cells.

\section{Autolysin-induced relaxation motions and fibre breakdown}

The relative contribution of the glycan moiety and the peptide cross-links to macrofibre shape maintenance was investigated by subjecting macrofibres to the action of glucosaminidase or amidase. FJ7 macrofibres produced at $20^{\circ} \mathrm{C}$ (right-handed) and $48^{\circ} \mathrm{C}$ (left-handed), and $\mathrm{C} 6 \mathrm{D}$ macrofibres produced at $20^{\circ} \mathrm{C}$ (left-handed), were transferred to a solution containing crude extract of autolysins diluted 10 -fold in TB medium and incubated at $20^{\circ} \mathrm{C}$. Two parallel series were examined: one at $\mathrm{pH} 5.6$ where the glucosaminidase activity is favoured, the other at $\mathrm{pH}$ 8.0 where the amidase activity is favoured (Brown \& Young, 1970). The reaction delay, nature of the relaxation and macrofibre breakdown were followed in both series (Table 3). Lysozyme-like relaxation motions were induced only at $\mathrm{pH} 5 \cdot 6$. Very short reaction delays were observed when left-hand macrofibres were the substrate, regardless of the temperature at which they were produced. At this $\mathrm{pH}$ no macrofibre breakdown was found, whereas at $\mathrm{pH} 8.0$ the macrofibre structure broke down, liberating lengths of cellular filaments that retained helical shape. Macrofibres of either hand incubated at each of the two $\mathrm{pH}$ values, without autolysins or crude extract, did not display any of the phenomena mentioned above. It appears therefore that the helical shape deformation is maintained by integrity of the glycan backbone rather than the peptide cross-links of the peptidoglycan.

\section{Effect of lysozyme digestion on twist and integrity of macrofibres following a temperature shift that leads to helix hand inversion}

The effect of lysozyme digestion on the twist and integrity of macrofibres grown at various temperatures has been dealt with previously (Mendelson et al., 1984). In the present study we investigated its effect during a temperature shift. As before the following parameters were measured: (i) maximum relaxation rate, (ii) time required for $50 \%$ of the cells to be converted to protoplasts and (iii) time required for breakdown of macrofibre structure.

Right-handed macrofibres of strain $\mathrm{FJ} 7$ produced at $20^{\circ} \mathrm{C}$ were transferred to $48^{\circ} \mathrm{C}$. Subsequently, samples were withdrawn at various times and exposed to lysozyme (Fig. 2). The maximum relaxation rate, approximately 5 turns $\mathrm{min}^{-1}$, remained constant during the lag between temperature shift and inversion (a $35 \mathrm{~min}$ period), then quickly increased to a plateau (about 12 turns $\mathrm{min}^{-1}$ ) which was sustained for at least $40 \mathrm{~min}$ (Fig. 2). The kinetics of macrofibre breakdown were similar: breakdown required 19 to $22 \mathrm{~min}$ for macrofibres sampled during the inversion lag; the breakdown rate then rapidly increased so that after a $50 \mathrm{~min}$ incubation at $48^{\circ} \mathrm{C}$ only about $3 \mathrm{~min}$ exposure to lysozyme was required for destruction of the macrofibre. The time required to convert $50 \%$ of the cells in a macrofibre to protoplasts changed approximately linearly as a function of incubation time at $48{ }^{\circ} \mathrm{C}$. It required about 212 minutes to convert $50 \%$ of the cells in right-handed macrofibres produced at $20^{\circ} \mathrm{C}$ to protoplasts whereas after $100 \mathrm{~min}$ incubation at $48^{\circ} \mathrm{C}$ the time required was only $63 \mathrm{~min}$ (Fig. 2 ). These results suggest that the time taken to digest the cell wall depends upon the proportion 


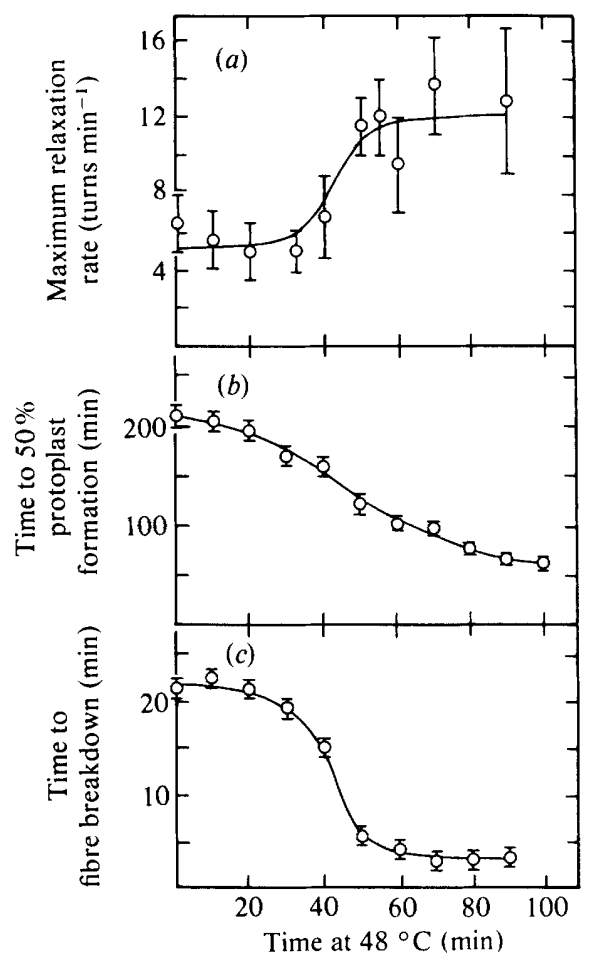

Fig. 2. Effect of lysozyme digestion on twist and integrity of macrofibres sampled from a population of FJ7 macrofibres following a shift-up from 20 to $48^{\circ} \mathrm{C}$. At the times indicated samples containing several macrofibres were removed and quickly chilled to $4{ }^{\circ} \mathrm{C}$ at which temperature they were held for at least $10 \mathrm{~min}$. The macrofibres were then transferred to either TB medium $(a)$ or to the osmotically stabilized medium SMMP ( $b$ and $c$ ) containing $5 \mathrm{mg}$ lysozyme $\mathrm{ml}^{-1}$. (a) All relaxation motions were observed directly using a stereoscopic dissection microscope. The start of motions and each halfrotation about the axis were recorded. Measurements were taken from small (two to eight strand structures) approximately $30 \mu \mathrm{m}$ in length that protruded from the shaft of large macrofibres. SD values were calculated using data from five to ten macrofibres for each sample. $(b)$ The time required to convert $50 \%$ of the cells to protoplasts was determined using a phase contrast microscope (magnification $400 \times$ ). (c) The time required for total macrofibre breakdown was determined by observation through a stereoscopic dissection microscope (magnification about $80 \times$ ). The end point was taken as the time when helical structures were no longer observable. Only short chains consisting of one to ten cell lengths remained.

of cell wall that was produced at $20^{\circ} \mathrm{C}$ relative to that produced at $48^{\circ} \mathrm{C}$. In contrast, both the maximum relaxation rate and the time required for breakdown of macrofibre structure appear to depend upon another time-dependent factor. This could be the region of the wall to which cell wall material of a particular conformation has been carried by upwelling during growth (Pooley, 1976), or some change in the wall polymers that influence twist, during their progress through the wall.

The parameters described above were measured in macrofibres after a temperature downshift from 48 to $20^{\circ} \mathrm{C}$. FJ7 macrofibres produced at $48^{\circ} \mathrm{C}$ (left-handed) were transferred to $20^{\circ} \mathrm{C}$ and samples were withdrawn at various times and exposed to lysozyme (Fig. 3). The maximum relaxation rate remained constant in the range characteristic of structures grown at $48{ }^{\circ} \mathrm{C}\left(14\right.$ to 19 turns $\left.\mathrm{min}^{-1}\right)$ for $70 \mathrm{~min}$ after transfer to $20^{\circ} \mathrm{C}$. At that time the rate decreased sharply to about 4 turns $\mathrm{min}^{-1}$, a rate similar to that found for steady state right-handed macrofibres grown at $20^{\circ} \mathrm{C}$ (Fig. 3). In contrast, the time required for lysozyme to break down macrofibre structure (about $4 \mathrm{~min}$ for left-handed structures produced at $48^{\circ} \mathrm{C}$ ) remained constant, after transfer of macrofibres to $20^{\circ} \mathrm{C}$, for at least the initial 220 min incubation 


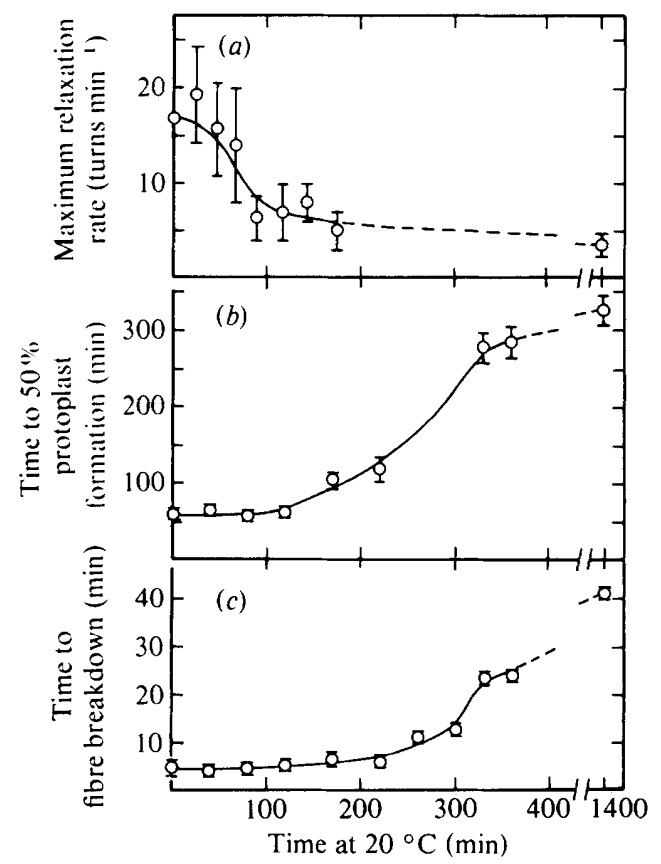

Fig. 3. Effect of lysozyme digestion on twist and integrity of macrofibres sampled from a population of FJ 7 macrofibres following a down-shift from 48 to $20^{\circ} \mathrm{C}$. Experimental details as in legend to Fig. 2.

following the temperature down-shift. Macrofibres incubated longer than 220 min after the temperature down-shift required progressively longer periods of exposure to lysozyme for breakdown. Eventually it required $40 \mathrm{~min}$ for lysozyme to destroy macrofibre structure (Fig. 3). Also shown in Fig. 3 is the time required for wall dissolution. In macrofibres sampled anytime during the initial $120 \mathrm{~min}$ after a temperature down-shift it required 55 to $65 \mathrm{~min}$ exposure to lysozyme to convert $50 \%$ of the cells to protoplasts. Macrofibres incubated longer than $120 \mathrm{~min}$ after transfer from 48 to $20^{\circ} \mathrm{C}$ required progressively longer exposures to lysozyme to reach this point. Eventually it required $320 \mathrm{~min}$ of lysozyme digestion to generate $50 \%$ protoplasts, a time typical for steady state macrofibres produced by growth at $20^{\circ} \mathrm{C}$ (Fig. 3).

\section{DISCUSSION}

The study of macrofibre susceptibility to enzyme attack provides evidence from which the role of cell wall polymers, in growth and in the maintenance of cell shape, can be inferred. If macrofibres are strained structures in which the outer portion of the cell wall plays a major part, then changes in the state of the peptidoglycan in the outer wall due to lysozyme attack should lead to marked changes in macrofibre geometry. By exploiting the known variation in macrofibre susceptibility to attack by lysozyme as a function of twist (including hand), and by using macrofibre mutants restricted to a narrow portion of the twist spectrum over the entire range of growth temperatures, we have found evidence that macrofibre twist and lysozyme sensitivity are based on the same factor, i.e. specific peptidoglycan conformation. We believe therefore that the physical state of the peptidoglycan is the basis for helical shape determination and maintenance.

Mature peptidoglycan consists of long glycan chains cross-linked by peptide bonds. Various linkages of the molecules can be cleaved by enzymes. We have studied the effect of hydrolysis on macrofibres at three different locations in the peptidoglycan. Lysozyme and glucosaminidase 
have been used to reduce the length of the glycan chains, and amidase to sever the linkage between them. We have found that relaxation motions are only induced when the glycan backbone is cut, which suggests that the helical shape is maintained by intact glycans. Cleavage of the peptide tail, in contrast, caused separation of sister cells by cutting at the cell septum. The cells liberated by subsequent breakdown of the macrofibre retained their helical shape. Thus cross-linking of the peptidoglycan apparently does not play a significant role in the maintenance of macrofibre twist.

Relaxation motions induced by cutting the glycan backbone always caused macrofibres first to turn towards the right-hand end of the twist spectrum regardless of the initial twist (or hand) of the macrofibre. This may indicate that a non-stressed, or most relaxed, state of the peptidoglycan in the cell wall exists that engenders macrofibre twist to the far-right of the twist spectrum. All macrofibres must be strained to the left of the spectrum relative to this most relaxed state, the most strained being tight left-handed macrofibres. The fact that macrofibres from the left-hand end of the twist spectrum respond more rapidly to peptidoglycan cleavage may reflect in part the higher degree of strain in such structures. The strained state may, for example, provide a more favourable structural conformation for attack by lysozyme and glucosaminidase. Possibly, the final motions observed in the left-hand direction immediately before breakdown of the structure result from septal cleavage or its equivalent which allows tension to be relieved along the length of individual cellular filaments.

The development of right-handed superstructure in left-hand macrofibres during relaxation motion may arise because the right-hand turning of the individual cellular filaments,. due to lysozyme action, is blocked by the restraint of the macrofibre structure. This is equivalent to the superimposition of a (left-hand) mechanical torsion on the lysozyme-induced turning. Such a torsion is relieved by folding in the right-hand sense. This is similar to the folding of a macrofibre during normal growth. In the latter situation, however, the restraint is provided by contact between macrofibres or, more usually, between different arms of the same macrofibre. Folding is always in the same sense as the attempted, but blocked, rotation (Mendelson, 1982).

The changes in macrofibre response to lysozyme digestion after a temperature shift provide new insight into cell wall structure and the helix hand inversion process. Following both up- and down-shift in temperature the maximum relexation rate remains constant for at least threequarters of the time taken to invert. Apparently, the state of wall strain is influenced by the newly inserted peptidoglycan only after it has migrated to some position in the mid to upper region of the cell wall. The very rapid initial mechanical response of macrofibres to lysozyme attack, and the speed with which relaxation is completed, are, moreover, evidence for a high degree of strain in the outer surface of the cell wall. Recent models of both Gram-positive and Gram-negative cell walls in which the degree of cross-linking of peptidoglycan varies as a function of location between the cytoplasmic membrane and the outer surface of the wall (Hobot et al., 1984; Koch \& Doyle, 1985) are compatible with this interpretation.

We attempted to use the time required to convert $50 \%$ of the cells in a macrofibre to protoplasts as a measure of the rate at which lysozyme digests the entire cell wall. Macrofibres that had been subjected to a temperature shift-up, and consequently had walls containing material of two different conformations with correspondingly different lysozyme sensitivities, provided results compatible with expectations based on ideas discussed earlier. The conversion time decreased progressively as a function of the length of time macrofibres were incubated at $48{ }^{\circ} \mathrm{C}$, reflecting the progressive replacement of right-hand wall by left-hand wall of greater lysozyme sensitivity. By contrast, the results obtained following a temperature down-shift indicate that the rapid rate of lysozyme attack characteristic of wall produced at $48^{\circ} \mathrm{C}$ is maintained for a long period during subsequent growth at $20^{\circ} \mathrm{C}$. It appears that wall newly synthesized at $20^{\circ} \mathrm{C}$ retains a conformation favourable for lysozyme attack beyond the time when the macrofibre assumes a right-handed orientation normally associated, during steady state growth, with lower lysozyme sensitivity. After prolonged growth at $20^{\circ} \mathrm{C}$ the right-handed macrofibres did eventually achieve the expected phenotype of lower lysozyme sensitivity.

Our experiments concerning enzyme-induced macrofibre breakdown provide additional information about septal peptidoglycan structure and metabolism. First, the preferential 
cleavage of septa by crude extract at the $\mathrm{pH}$ favouring amidase action suggests that peptide cross-links are of particular importance in linking sister cells to one another. Second, in this and previous work (Mendelson et al., 1984) we have observed that rates of septal cleavage by lysozyme parallel to some extent the rates of lateral wall susceptibility as indicated by relaxation rate; that is, they vary as a function of macrofibre twist. It appears therefore that some aspect of peptidoglycan structure related to twist must reside in both the septal and lateral wall peptidoglycans. Third, the kinetics of septal cleavage in macrofibres after a temperature shift which leads to helix hand inversion indicate that septal wall is continuously renewed in the same way as lateral cell wall. These studies did not, however, reveal any role for septal peptidoglycan in either helical twist or cell wall strain maintenance.

All the results reported in this paper suggest a model of cell growth, shape determination and shape maintenance in which the biomechanical properties of the cell wall polymers are of central importance. In the macrofibre system shape determination and maintenance appear to result from mechanical interactions among cell wall components. Such interactions must surely also be of importance in the determination and maintenance of normal cell shape.

This work was supported by research grants from the National Institute of General Medical Sciences, and the National Science Foundation (PCM-8104192) (to N.H.M.). D.F. was supported by a grant from the Swiss National Science Foundation.

\section{REFERENCES}

Brown, W. C. \& Young, F. E. (1970). Dynamic interaction between cell wall polymers, extracellular protease and autolytic enzymes. Biochemical and Biophysical Research Communications 38, 546-568.

FAVRE, D. (1984). Comportments des macrofibres de Bacillus subtilis en fonction de la temperature et leur correlation avec la structure et la reorganisation de la paroi bacterienne. $\mathrm{PhD}$ thesis, University of Lausanne, Switzerland. (In French.)

FaVre, D., Karamata, D. \& Mendelson, N. H. $(1985 a)$. Temperature-pulse-induced "memory" in Bacillus subtilis macrofibers and a role for protein(s) in the left-handed twist state. Journal of Bacteriology 164, 1141-1145.

Favre, D., Thwaites, J. J. \& Mendelson, N. H. $(1985 \mathrm{~b})$. Kinetic studies of temperature-induced helix hand inversion in Bacillus subtilis macrofibers. Journal of Bacteriology 164, 1136-1140.

FEIN, J. E. \& Rogers, H. J. (1976). Autolytic enzymedeficient mutants of Bacillus subtilis. Journal of Bacteriology 127, 1427-1442.

Hobot, J. A., Carlemalm, E., Villiger, W. \& Kellenberger, E. (1984). Periplasmic gel: new concept resulting from the reinvestigation of bacterial cell envelope ultrastructure by new methods. Journal of Bacteriology 160, 143-152.

Imoto, T., Johnson, L. N., NoRth, D. C., Phillips, D. C. \& RuPLEY, J. A. (1972). Vertebrate lysozyme. In The Enzymes, vol. 7, pp. 665-868. Edited by P. D. Boyer. New York: Academic Press.
KoCH, A. L. \& DOYLE, R. J. (1985). Inside-to-outside growth and turnover of the wall of the Gram-positive rod. Journal of Theoretical Biology 117, 137-157.

Mendelson, N. H. (1976). Helical growth of Bacillus subtilis: a new model of cell growth. Proceedings of the National Academy of Sciences of the United States of America 73, 1740-1744.

MENDELSON, N. H. (1978). Helical Bacillus subtilis macrofibers: morphogenesis of a bacterial multicellular macroorganism. Proceedings of the National Academy of Sciences of the United States of America 75, 2478-2482.

Mendelson, N. H. (1982). Dynamics of Bacillus subtilis helical macrofiber morphogenesis: writhing, folding, close packing and contraction. Journal of Bacteriology 151, 438-449.

Mendelson, N. H., Favre, D. \& Thwaites, J. J. (1984). Twisted states of Bacillus subtilis macrofibers reflect structural states of the cell wall. Proceedings of the National Academy of Sciences of the United States of America 81, 3562-3566.

Mendelson, N. H., Thwaites, J. J., Favre, D., Surana, U., Briehl, M. M. \& Wolfe, A. J. (1985). Factors contributing to helical shape determination and maintenance in Bacillus subtilis macrofibres. Annales de l'Institut Pasteur/Microbiologie 136S, 99103

PoOLey, H. M. (1976). Layered distribution according to age within the cell wall of Bacillus subtilis. Journal of Bacteriology 125, 1139-1147. 